\title{
БУДІВЕЛЬНІ КОНСТРУКЦІї
}

\section{ВПЛИВ ДІАПАЗОНУ ЧАСТОТИ І ТОВЩИНИ ПАНЕЛІ ІЗ ЗАСТОСУВАННЯМ ГУМОВОЇ КРИХТИ НА ЗНАЧЕННЯ ІНДЕКСУ ЗВУКОІЗОЛЯЦЇ̈}

\begin{abstract}
Одеська державна академія будівництва та архітектури
Стаття присвячена питанню підвищення показника звукоізоляції в конструкції стінової панелі. Для вирішення такої проблеми було проведено аналіз впливу частоти і гранулометричного складу суміші на значення індексу звукоізоляції. Також було показано варіювання величини звукоізоляції в залежності від товщини стінової панелі, яка була виготовлена з використанням гумової крихти. Розглянуто способи отримання і спектр застосування в сучасній промисловості гумової крихти, як матеріалу подрібнення зношених шин, що є одним з найбільш багатотоннажних полімерних відходів. Проілюстровано структуру установки звукоізоляційних панелей під час проведення експерименту. Результати визначення рівня звукоізоляції були порівняні та представлені на діаграмах для кожної групи окремо.
\end{abstract}

Ключові слова: звукоізоляція, рециркульована гумова панель, індекс звукоізоляції, діапазон частот.

\section{Вступ}

В даний час гостро стоїть проблема повторного застосування матеріалів. Одним 3 таких матеріалів $\epsilon$ використані автомобільні шини. Найбільше застосування вони отримали в дорожньому будівництві, для благоустрою територій спортивних майданчиків, при ремонті мостів та трубопроводів. А в останні роки їх використовують і для виробництва звукоізоляційних панелей.

Рециркульована гумова панель являє собою високоефективний звукоізоляційний матеріал 3 відносно хорошими механічними властивостями. Ці властивості дозволяють використовувати його в різних легких конструкціях в якості матеріалу, який підсилює структурну звукоізоляцію і зменшує вібрацію. У процесі регенерації шини спочатку проводиться ії нагрівання, а потім поділ металу, текстильних і гумових гранул. Гранули подрібнюють, просівають, піддають дії пару i різних хімічних речовин з метою видалення сірки (девулканізація) [1]. Весь процес механічного подрібнення і сепарації відбувається при температурі повітря близько $80^{\circ} \mathrm{C}$. Отриману суміш поміщають в камери, додають

4-6\% поліуретанового клею, нагрівають до $110^{\circ} \mathrm{C}$ і укладають в прес-форму, пресовану при заданому навантаженні протягом регламентованого періоду часу.

Застосування таких панелей $є$ економічно доцільним у багатьох областях будівництва. Метою даної роботи $\epsilon$ вивчення впливу товщини панелей i діапазону частоти на значення індексу звукоізоляції.

\section{Основна частина}

Всі дослідження описані в даній роботі проводилися відповідно до стандарту HRN EN ISO 7171:2013 [2]. Даний нормативний документ регламентує оцінку звукоізоляції в конструктивних елементах будівель, таких як стіни, підлоги, вікна, двері та враховує різні зовнішні і внутрішні джерела шуму. Також цей документ містить методи, що визначають результати вимірювань $\mathrm{i}$ їх перетворення в значення звукоізоляції будівельного елементу, виражене одним числом.

В ході представлених досліджень були вивчені вплив товщини та щільності панелі, гранулометричного складу зерен, а також частотного діапазону на звукоізоляцію панелі.

Першим змінним параметром $\epsilon$ товщина панелі, яка варіювалася в трьох розмірах: 10,15 і 20 мM.

Другий параметр - щільність панелі, в залежності від показників якої зразки були згруповані таким чином: близько 600 кг $/ \mathrm{M}^{3}$, близько 700 кг $/ \mathrm{M}^{3}$, близько 900 кг $/ \mathrm{M}^{3}$. 
Третій параметр - гранулометричний склад суміші, який змінювався в такий спосіб:

0,5-2 мм; 2-3,5 мм; 0,5-2 мм * 35\% + 2-3,5 мм *65\%.

Разом $з$ цим вимірювання звукоізоляції проводилися для різних діапазонів частот: низькі (до 500 Гц), середні (500-2000 Гц) і високі (2000-5000 Гц). Зразки були виготовлені в компанії Gumi Impex в м. Вараждін (Хорватія), що займається виробництвом і переробкою автомобільних шин.

Експеримент проводився в Лабораторії будівельної фізики i акустичних випробувань хорватського інституту будівництва (IGH).

Приймальна кімната була повністю відокремлена від кімнати, де знаходилося джерело звуку. Існуючий проріз в стіні, що розділяв кімнати, призначений для випробування звукоізоляційних властивостей вікон і дверей. Площа експериментальних зразків становила $0,75 \mathrm{~m}^{2}$, що відповідає розміру віконного отвору. Слід зазначити, що питома вага зразків для високого поглинання звуку становить від 180 до 250 кг/м ${ }^{3}$ [3].

Зразки вбудовувалися в коробку подібну віконному блоку (рис.1, 2, 3).
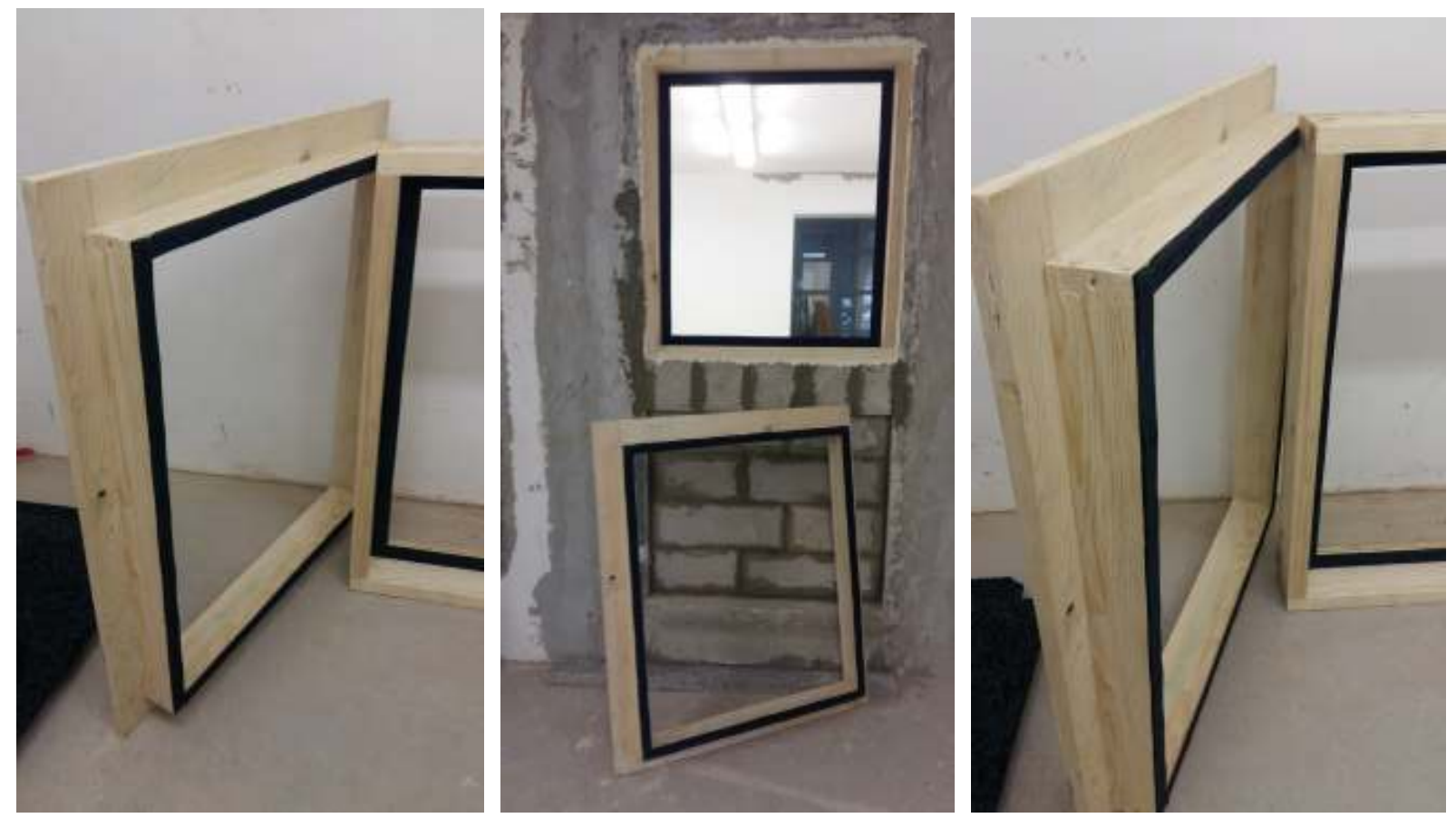

Рисунок 1, 2, 3 - Установка звукоізоляційних панелей під час проведення експерименту

Значення звукоізоляції перегородки між кімнатою приймача і кімнатою передавача становить приблизно 75 дБ. Згідно з нормативним документом [2] необхідно щоб значення звукоізоляції за рахунок досліджуваного зразка відрізнялося не менше ніж на

1 дБ. При цьому необхідно забезпечити такі умови, щоб значення звукоізоляції розділової конструкції не впливало на отримані результати.

Звуковий приймач являв собою мікрофон на спеціальній підставці, яка обертається в декількох площинах і повністю акумулює звук, що надходить від передавача (рис.4, 5, 6).

Вимірювання відбувалося таким чином, що звукова потужність близько 105 дБ випромінювалася протягом 60 секунд в два етапи.

Всього було випробувано 27 зразків різної товщини, ваги і гранулометричного складу. При цьому всі зразки були розділені на 3 групи:

- до першої групи належали зразки 3 питомою вагою 585-600 кг та однаковим гранулометричним складом, в якому фракція гранул складала від 0,5 до 2,0 мм. Змінним коефіцієнтом була товщина панелі - 15 і 20 мм;

- до другої групи належали зразки 3 питомою вагою $700-750 \quad$ кг/ $\mathrm{m}^{3} 3$ однаковим гранулометричним складом, в якому фракція гранул складала від 0,5 до 2,0 мм. Змінним коефіцієнтом була товщина панелі - 10, 15 і 20 мм;

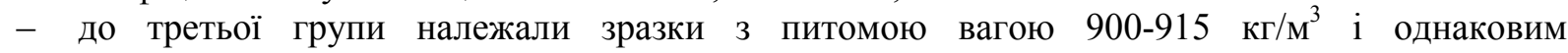
гранулометричним складом. Розмір гранул становив від 0,5 до 2,0 мм. Змінним коефіцієнтом була товщина панелі - 10, 15 і 20 мм. 

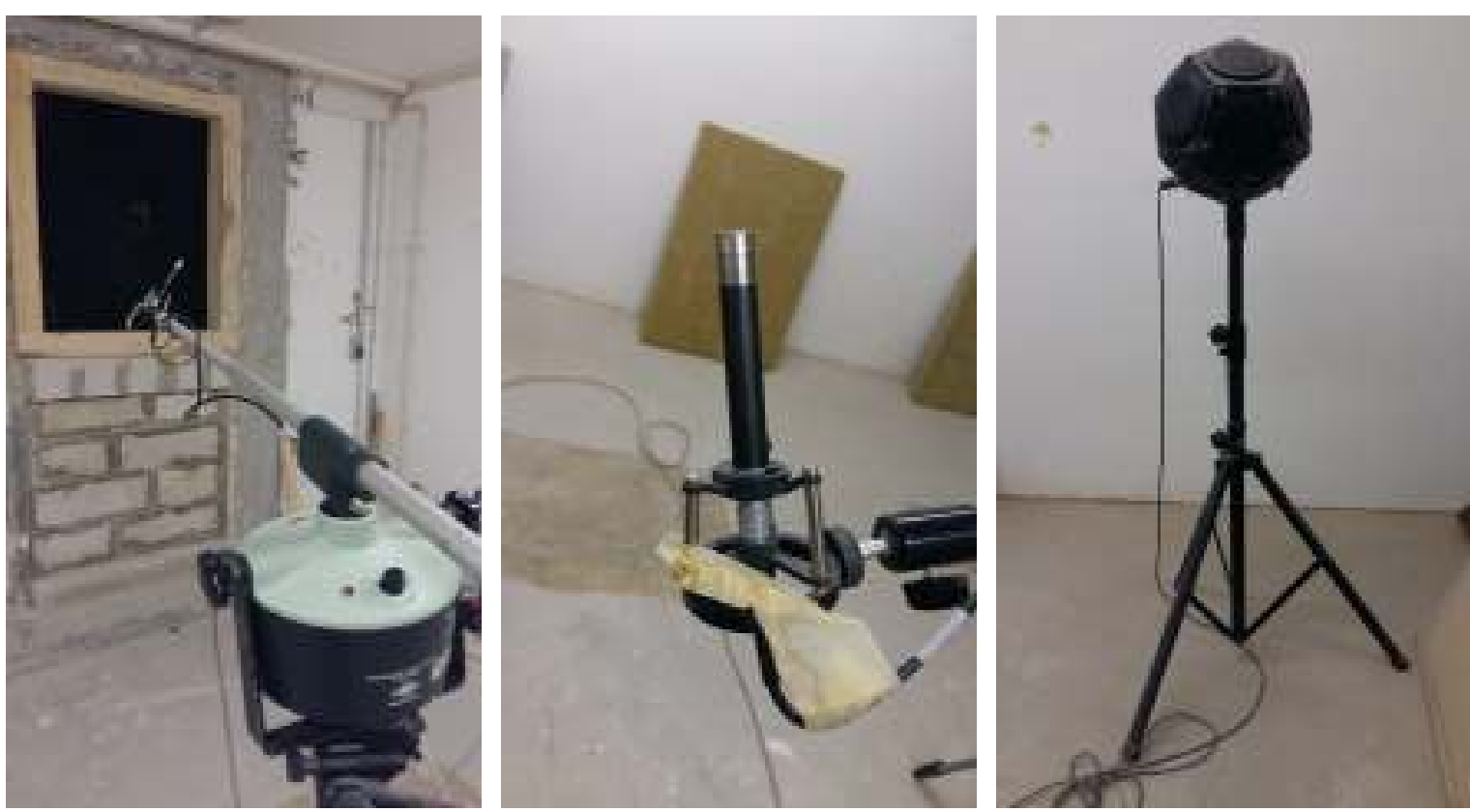

Рисунок 4, 5, 6 - Приймач і передавач звуку

У таблицях 1-3 показана комбінація шаблонів з фіксованими і змінними факторами.

Група зразків № 1

Таблиця 1

\begin{tabular}{|c|c|c|c|}
\hline № $\Pi / \Pi$ & Товщина (мм) & Маса $\left(\kappa г / \mathrm{M}^{3}\right)$ & $\begin{array}{c}\text { Гранулометричний } \\
\text { склад }\end{array}$ \\
\hline 10. & 15 & 600 & $05-20$ \\
\hline 19. & 20 & 585 & $05-20$ \\
\hline
\end{tabular}

Група зразків № 2

Таблиця 2

\begin{tabular}{|c|c|c|c|}
\hline № $\Pi / \Pi$ & Товщина (мм) & Маса $\left(\kappa г / \mathrm{M}^{3}\right)$ & $\begin{array}{c}\text { Гранулометричний } \\
\text { склад }\end{array}$ \\
\hline 1. & 10 & 700 & $05-20$ \\
\hline 13. & 15 & 750 & $05-20$ \\
\hline 22. & 20 & 750 & $05-20$ \\
\hline
\end{tabular}

Група зразків № 3

\begin{tabular}{|c|c|c|c|}
\hline № $\Pi / \Pi$ & Товщина (мм) & Маса $\left(\kappa г / \mathbf{M}^{3}\right)$ & $\begin{array}{c}\text { Гранулометричний } \\
\text { склад }\end{array}$ \\
\hline 4. & 10 & 900 & $05-20$ \\
\hline 16. & 15 & 915 & $05-20$ \\
\hline 25. & 20 & 915 & $05-20$ \\
\hline
\end{tabular}

Результати експериментів визначення рівня звукоізоляції представлені для кожної групи окремо на діаграмах [Рис. 7-9]. На наведених діаграмах відображена залежність між індексом значень звукової ізоляції для кожної $з$ досліджуваних панелей.

На рис.7 представлено порівняння 2 зразків товщиною 15 мм $\left(600 \mathrm{\kappa r} / \mathrm{m}^{3}\right)$ і $20 \mathrm{мм}\left(585 \mathrm{\kappa r} / \mathrm{m}^{3}\right)$ (Група №1). 3 діаграми можна зробити висновок що в даному випадку звукоізоляція панелей дуже однорідна і обидві панелі мають майже однакові результати. При цьому видно, що більшого впливу на звукоізоляцію панелей надає зміна частотного діапазону. 


\section{ПОРІВНЯННЯ РЕЗУЛЬТАТІВ ПАНЕЛЕЙ №.№10, 19}

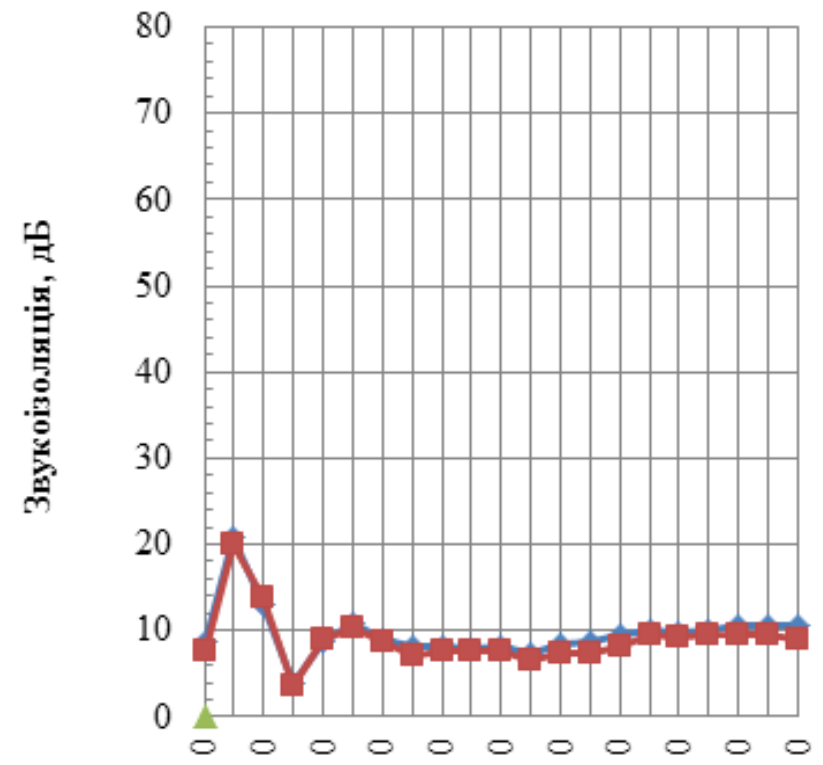

Частота, Гц

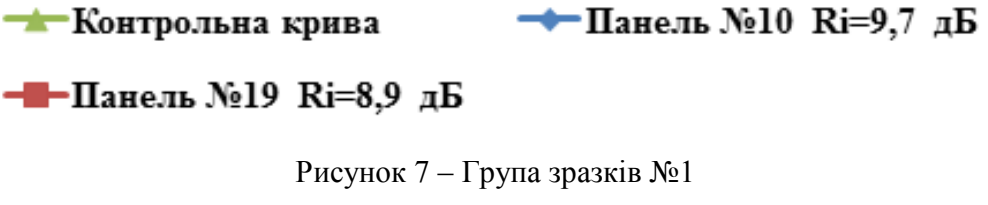

ПОРІВНЯННЯ РЕЗУЛЬТАТІВ ПАНЕЛЕЙ №№1, 13, 22

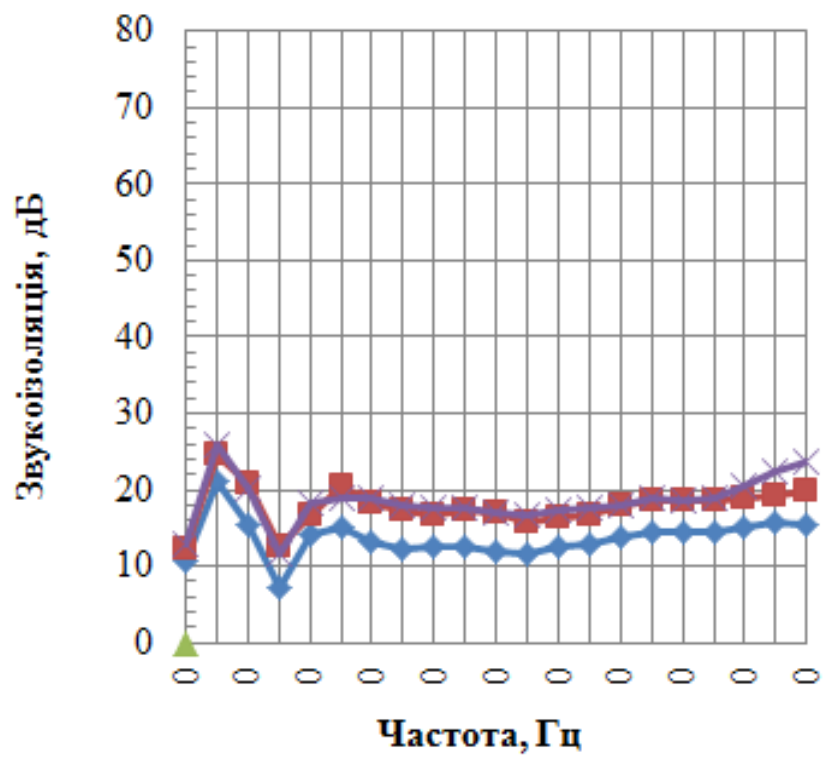

\footnotetext{
- Контрольна крива

- -Панель №l Ri=14 дБ

Панель №l3 $\mathrm{Ri}=18,2$ дБ

ЖПанель № $22 \mathrm{Ri}=18,8$ дБ

Рисунок 8 - Група зразків №2
} 


\section{ПОРІВНЯННЯ РЕЗУЛЬТАТІВ ПАНЕЛЕЙ №№4, 16, 25}
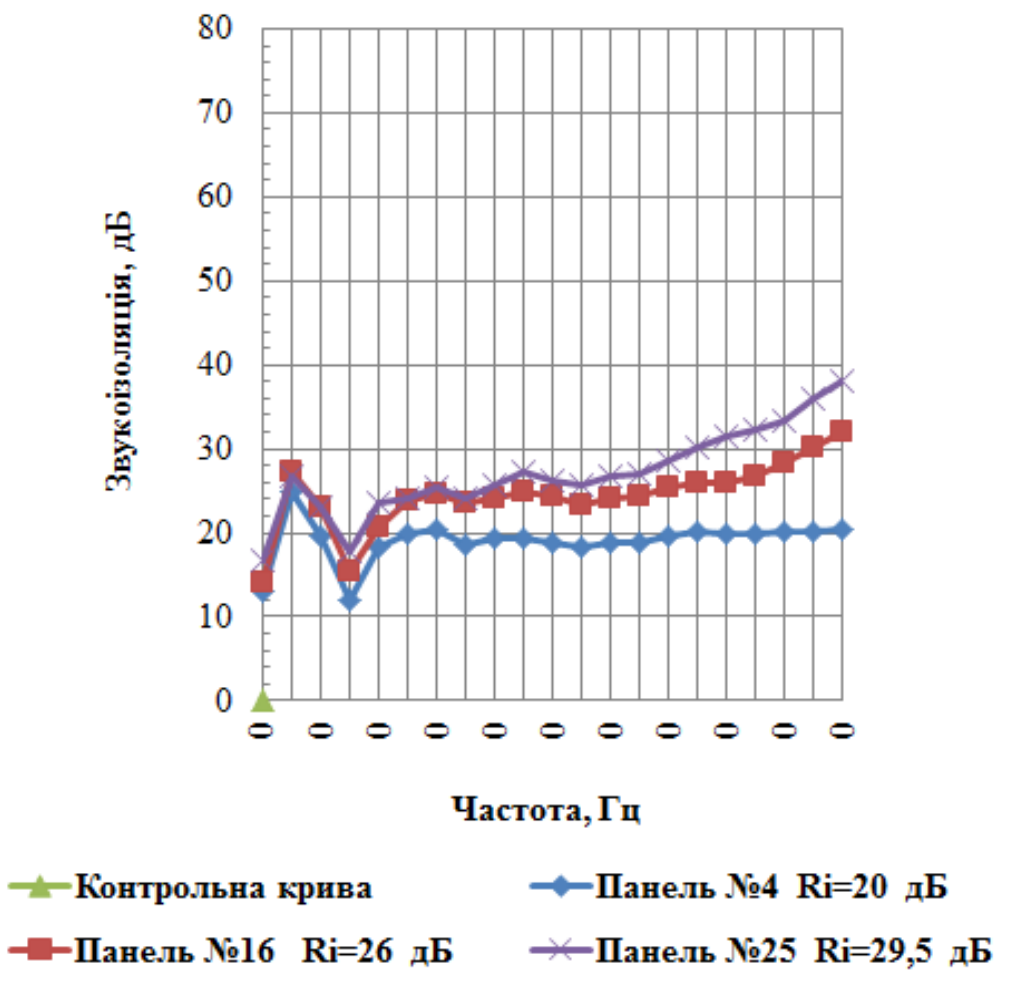

Рисунок 9 - Група зразків № 3

Так, в низькочастотній смузі для товщини панелі 15 мм значення звукоізоляції вище на 0,3-0,9 дБ. В середньому діапазоні частот для товщини панелі 15 мм значення звукоізоляції вище на 0,61,3 дБ. У високочастотному діапазоні товщини панелі 15 мм значення звукоізоляції вище на 0,61,6 дБ.

У другій групі (рис.8) порівнювалися 3 зразка товщиною 10 мм $(700$ кг/м³ $), 15$ мм $\left(750 \mathrm{\kappa} / \mathrm{M}^{3}\right)$ і 20 мм $\left(750 \mathrm{\kappa} / \mathrm{m}^{3}\right)$. На відміну від першої групи, в даному випадку, звукоізоляція зразків показала істотні відмінності. Значення звукоізоляції панелі товщиною 10 мм становить 14 дБ, звукоізоляція панелі товщиною 15 мм - 18,2 дБ, а звукоізоляція панелі товщиною 20 мм - 18,8 дБ. 3 діаграми видно значно менше значення звукоізоляції панелі товщиною 10 мм в порівнянні 3 панелями товщиною 15 і 20 мм. Цей факт можна пояснити меншою питомою вагою зразка. Тому доцільно розглянути вплив частотних діапазонів на звукоізоляцію даних панелей.

В низькому діапазоні для панелі товщиною 20 мм значення звукоізоляції $є$ непостійним. Діаграма показує що при частотах 80, 100 і 160 Гц спостерігається мінімальна звукоізоляція навіть до 1,4 дБ, тоді як для решти низькочастотного діапазону звукоізоляція більше на 0,1-0,9 дБ.

У середній смузі частот для товщини панелі 20 мм значення звукоізоляції більше на 0,0-0,9 дБ.

У високочастотній смузі для товщини панелі 20 мм значення звукоізоляції більше на 0,3-3,8 дБ.

У третій групі (рис. 9) порівнювалися 3 зразка товщиною 10 мм $\left(900\right.$ кг $\left./ \mathrm{M}^{3}\right), 15$ мм

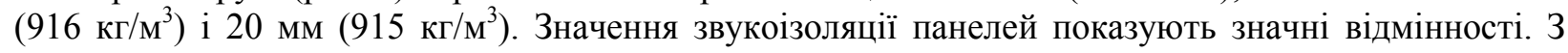
діаграми видно, що значення звукоізоляції панелі товщиною 10 мм становить 20 дБ. Звукоізоляція при товщині панелі 15 мм становить 26 дБ, а звукоізоляція панелі товщиною 20 мм становить 29,5 дБ.

У низькочастотній смузі для товщини панелі 20 мм значення звукоізоляції є непостійним. Це означає, що на частоті 63 Гц звукоізоляція менше на 0,4 дБ, тоді як для решти низькочастотної смуги звукоізоляція вище для 0,1-2,8 дБ. У центральному діапазоні частот для товщини панелі 20 мм значення звукоізоляції вище на 2,4-5,4 дБ. У високочастотній смузі для товщини панелі 20 мм величина звукоізоляції вище на 5,2-6 дБ. 


\section{Висновок}

На основі отриманих результатів можна зробити висновок що питома вага значно впливає на показник звукоізоляції.

При меншій питомій вазі виникає умова, за якої товщина панелі не робить істотного впливу. Це означає, що при однакових питомих вагах, товщина панелі не вплине на величину іiі звукоізоляції. Причина полягає в більш високій пористості і пропускній здатності.

1. При високій питомій вазі товщина панелі значно впливала на величину звукоізоляції. Велика питома вага має на увазі більш низький обсяг пір, велику компактність, низьку пропускну здатність і поліпшену звукоізоляцію.

2. Для зразків 3 питомою вагою $750 \mathrm{\kappa} / \mathrm{m}^{3}$ і вище значення звукоізоляції не перевищують необхідний мінімум в 10 Гц. Отже їх використання для поліпшення звукоізоляційних властивостей будівельних конструкцій $є$ недоцільним.

\section{СПИСОК ЛІТЕРАТУРИ}

1. Gumiimpex-GRP. [Електронний ресурc]. - Режим доступу: http://gumiimpex.hr.

2. HRN EN ISO 717-1:2013 Acoustics. Rating of sound insulation in buildings and of building elements.

3. Jimenez-Espadafor F. J. Optimal design of acoustic material from tire fluff / F. J. Jimenez-Espadafor, J. B. Villanueva, M. T. García, E. C. Trujillo, A. M. Blanco // Elsevier, Materials and Design. - 2011. - №32. P. 3608-3616.

\section{REFERENCES}

1. Gumiimpex-GRP. [Elektronnyy resurs]. - Rezhym dostupu: http://gumiimpex.hr.

2. HRN EN ISO 717-1: 2013 Akustyka. Otsinka zvukoizolyatsiyi v budivlyakh i budivel'nykh elementakh.

3. Jimenez-Espadafor F. J. Optymal'ne proektuvannya akustychnoho materialu z shynnoho pukhu / F. J. Jimenez-Espadafor, J. B. Villanueva, M.T. - 2011. - №32. R. 3608-3616.

Попов Олег Олександрович - канд. техн. наук, доцент кафедри технології будівельного виробництва Одеської державної академії будівництва та архітектури. ORCID: 0000-0003-4021-5199.

Гострик Анна Миколаӥвна - аспірант Одеської державної академії будівництва та архітектури. anna.gostryk16@gmail.com. ORCID: 0000-0002-1638-0912.

Црноя Анжелко - аспірант Одеської державної академії будівництва та архітектури. ORCID: 0000-00019557-9411.

O. Popov

A. Hostryk

A. Crnoja

\section{THE EFFECT THICKNESS OF THE PANEL WITH THE APPLICATION OF RUBBER CRUMB AND FREQUENCY RANGE ON THE VALUE OF THE SOUND INSULATION INDEX}

Odessa State Academy of Civil Engineering and Architecture

The article is devoted to the issue of increasing the level of sound insulation in the construction of a wall panel. To solve this problem, an analysis was made of the effect of the frequency and particle size distribution of the mixture on the value of the sound insulation index. It was also shown varying the amount of sound insulation depending on the thickness of the wall panel, which was made using rubber crumb. The methods of production and the range of application in the modern industry of crumb rubber as a material of grinding worn tires, which is one of the most large-capacity polymeric wastes, are considered. The installation structure of sound insulation panels during the experiment is illustrated. The results of determining the level of sound insulation were compared and presented on the diagrams for each group separately.

Keywords: sound insulation, recycled rubber panel, sound insulation index, frequency range.

Oleg Popov - Ph.D., assistant professor of Department of Technology of building production, Odessa State Academy of Civil Engineering and Architecture

Anna Hostryk - postgraduate student, Odessa State Academy of Civil Engineering and Architecture

Andjelko Crnoja - postgraduate student, Odessa State Academy of Civil Engineering and Architecture 
О. А. Попов

А. Н. Гострик

А. Црноя

\title{
ВЛИЯНИЕ ТОЛЩИНЫ ПАНЕЛИ С ПРИМЕНЕНИЕМ РЕЗИНОВОЙ КРОШКИ И ДИАПАЗОНА ЧАСТОТЫ НА ЗНАЧЕНИЕ ИНДЕКСА ЗВУКОИЗОЛЯЦИИ
}

\author{
Одесская государственная академия строительства и архитектуры
}

Статья посвящена вопросу повышения показателя звукоизоляции в конструкции стеновой панели. Для решения такой проблемы был проведен анализ влияния частоты и гранулометрического состава смеси на значение индекса звукоизоляции. Также было показано варьирование величины звукоизоляции в зависимости от толщины стеновой панели, которая была изготовлена с использованием резиновой крошки. Рассмотрены способы получения и спектр применения в современной промышленности резиновой крошки в качестве материала измельчения изношенных шин, который является одним из самых многотоннажных полимерных отходов. Проиллюстрировано структуру установки звукоизоляционных панелей во время проведения эксперимента. Результаты определения уровня звукоизоляции были сравнены и представлены на диаграммах для каждой группы отдельно.

Ключевые слова: звукоизоляция, рециркулированная резиновая панель, индекс звукоизоляции, диапазон частот.

Попов Олег Александрович - канд. техн. наук, доцент кафедры технологи строительного производства Одесской государственной академии строительства и архитектуры.

Гострик Анна Николаевна - аспирант Одесской государственной академии строительства и архитектуры. Црноя Анджелко - аспирант Одесской государственной академии строительства и архитектуры. 